\title{
EVALUASI KONDISI OPERASI PROSES PENCAMPURAN BAHAN PADA PEMBUATAN PRODUK CHLOROPRENE RUBBER (STUDI DESKRIPTIF DI INDUSTRI POLIMER)
}

\author{
Ishmar Balda Fauzan1), Nelsa Rahmita2), Bintang Iwhan Moehady3) \\ Jurusan Teknik Kimia, Politeknik Negeri Bandung,Bandung 40012 \\ E-mail:1)ishmarbldf@gmail.com,3)nelsarahmita@yahoo.co.id, 3)bintang@polban.ac.id
}

\begin{abstract}
ABSTRAK
Chloroprene rubber adalah salah satu jenis karet sintetis yang biasa dikenal dengan namaNeoprene. Proses pembuatan chloroprene rubber dengan cara pencampuran bahan-bahan yang terdiri dari polimer, oil, bahan kimia, carbon, dan accelerator. Pencampuran chloroprene rubber menggunakan mesin mixing yang dinamakan kneader.Pada produksi chloroprene rubber di industri, terdapat dispersi bintik putih. Penelitian ini bertujuan untuk menentukan kondisi operasi optimum pada proses pencampuran bahan pada produksi chloroprene rubber yang tidak terdispersi, terdispersi, dan mendapatkan efisiensi pencampuran. Indikator keberhasilan proses yaitu jika tidak terdapat bintik putih secara visual dan memiliki persen dispersi $<0,5 \%$. Evaluasi terhadap produk chloroprene rubber dilakukan dengan menganalisis \% jumlah produk chloroprene rubber yang terdispersi bintik putih dengan cara visual dan mengevaluasi kondisi proses dengan beberapa variasi. Kondisi operasi proses meliputi temperatur pencampuran, kecepatan putar rotor, dan waktu pencampuran. Variasi temperatur operasi yang diambil adalah $72^{\circ} \mathrm{C}, 74^{\circ} \mathrm{C}, 76^{\circ} \mathrm{C}, 78^{\circ} \mathrm{C}$, dan $86^{\circ} \mathrm{C}$. Kecepatan putar rotor dengan variasi $21 \mathrm{rpm}, 23 \mathrm{rpm}, 25 \mathrm{rpm}, 28 \mathrm{rpm}$, dan 30rpm. Variasi waktu pencampuran yaitu pada 14,5 menit, 15 menit, 17 menit, 18 menit, dan 20 menit. Hasil penelitian menunjukkan bahwa kondisi operasi optimum terjadi pada $86^{\circ} \mathrm{C}, 30 \mathrm{rpm}$, dan 18 menit yaitu produk tidak memiliki bintik putih, dengan jumlah produk terdispersi $0,49 \%$ dan memiliki efisiensi pencampuran sebesar 4,5\%, sehingga memenuhi kriteria indikator keberhasilan.
\end{abstract}

Kata kunci

Chloroprene rubber, efisiensi pencampuran, kecepatan putar rotor, temperatur pencampuran, waktu pencampuran.

\section{PENDAHULUAN}

Karet alam merupakan politerpena yang disintesis secara alami melalui polimerisasi enzimatik isopentil pirofosfat, yang bentuk utamanya terdiri dari $97 \%$ cis $1-4$ isoprena atau dikenal dengan hevea ruber (Malcom,P.S., 2001). Karet alam hanya dihasilkan oleh negara-negara beriklim tropis, sehingga produksinya tidak dapat memenuhi kebutuhan karet dunia. Kondisi ini mendorong negara-negara barat untuk melakukan serangkaian penelitian guna memproduksi karet sintetis atau karet buatan (Matondang, 2010). Maka dari itu, ada dua jenis karet, yaitu karet alam dan karet sintetis.
Karet sintetis sebagian besar dibuat dengan mengandalkan bahan baku minyak bumi yang telah dipelopori dan dikembangkan oleh negara-negara maju secara besar-besaran sejak zaman perang dunia II (Matondang, 2010). Perkembangan karet sintetis hingga saat ini telah menjadikan jenis karet sintetis yang beragam dan memiliki sifat tersendiri yang khas seperti; tahan terhadap panas atau suhu tinggi, minyak, pengaruh udara, dan bahkan ada yang kedap air. Karet sintetis jenis chloropene rubber yang paling dikenal dan menguasai pasaran internasional (Wikipedia, 2015).

Karet sintetis chloroprene rubber (CR) biasa 
disebut neoprene atau juga polychloroprene. Neoprene merupakan keluarga karet sintetis yang diproduksi dari polimerisasi chloroprene. Karet sintetis chloroprene rubber mempunyai kelebihan tahan api, untuk pembuatan pipa karet, pembungkus kabel, seal, gasket sabuk/ban conveyor (Wikipedia, 2005). Cara produksi karet chloroprene rubber dengan mencampurkan bahan yang terdiri dari polimer, oil, karbon, dan bahan kimia secara bertahap kedalam suatu alat mixing (kneader) (Arizal, 1994).

Sejak awal bulan Oktober tahun 2014 di salah satu pabrik ditemukan produk chloroprene rubber yang menghasilkan produk mengandung dispersi bintik putih. Produk dengan dispersi bintik putih tersebut mempengaruhi kualitas produk yang memberi dampak pada penurunan kapasitas produksi. Penemuan bintik putih tersebut belum pernah ada yang mengkaji dan mendalami untuk mendapatkan solusinya, sehingga masalah tersebut perlu kajian lebih lanjut dalam bentuk evaluasi dan optimasi terhahap kondisi operasi yang berlangsung di pabrik

Tujuan dari penelitian ini adalah sebagai berikut:

1. Mendapatkan waktu, suhu, dan putaran rotor pada proses pencampuran bahan dalam produksi chloroprene rubber dengan hasil tanpa bintik putih dan produk terdispersi $<0,5 \%$ sesuai standar pabrik yang diteliti.

2. Mendapatkan kondisi operasi produksi chloroprene rubber yang terdispersi dengan bintik putih.

\section{METODE}

Masalah yang terjadi terdapat pada produk chloroprene rubber (CR) yaitu terjadinya dispersi bintik putih yang disebabkan oleh kondisi operasi yang berbeda dengan referensi. Setelah masalah diketahui dilakukan studi lapangan dan studi literatur yang merupakan tahap untuk memastikan kesesuaian kondisi operasi dengan teori. Studi literature juga sebagai acuan untuk mendapatkan produk yang lebih baik pada proses berikutnya. Pengumpulan data merupakan tahap selanjutnya, kemudian akan dilakukan pengolahan data dan analisis hasil. Hasil yang akan dianalisis berupa \% jumlah produk chloroprene rubber yang terdispersi bintik putih. Analisis dilakukan dengan cara visual dan membandingkan produk chloroprene rubber yang terdispersi bintik putih dengan produk yang tidak terdapat bintik putih. Pembahasan dilakukan setelah analisis hasil selesai. Hal yang akan dibahas adalah kondisi operasi mengenai pengaruh waktu pencampuran, putaran rotor, dan suhu pencampuran. Selain kondisi operasi, hal yang akan dibahas yaitu perbandingan antara $\%$ jumlah produk chloroprene rubber yang terdispersi dan yang tidak terdispersi.

\section{HASIL DAN PEMBAHASAN}

\subsection{Hasil Pencampuran dengan Variasi Suhu}

Hasil pencampuran pada range suhu $70-90^{\circ} \mathrm{C}$ dengan putaran rotor $28 \mathrm{rpm}$ dan waktu pencampuran 14,5 menit adalah sebagai berikut:

Tabel 1: Hasil Pencampuran dengan Variasi Suhu

\begin{tabular}{cc}
\hline $\begin{array}{c}\text { Suhu } \\
\text { Pencampuran } \\
\left({ }^{\circ} \mathbf{C}\right)\end{array}$ & $\begin{array}{c}\text { \% Jumlah Produk } \\
\text { Terdispersi }\end{array}$ \\
\hline 72 & 3,14 \\
74 & 2,81 \\
76 & 2,34 \\
78 & 1,74 \\
86 & 1,51 \\
\hline
\end{tabular}

Dari Tabel 1 bahwa pada suhu $86^{\circ} \mathrm{C}$ memiliki jumlah produk terdispersi sebesar 1,51\%. Berdasarkan tabel tersebut dapat dilihat bahwa semakin tinggin suhu, semakin kecil \% jumlah produk terdispersinya. Semakin tinggi suhu bahan-bahan baku pembuat karet jenis chloroprene rubber terhomogenisasi dengan 
baik (Chapman \& Hall, 1949).

\subsection{Hasil Pencampuran dengan Variasi Waktu Pencampuran}

Hasil pencampuran pada range waktu pencampuran 14,5-18 menit dengan putaran rotor $28 \mathrm{rpm}$ dan suhu pencampuran $86^{\circ} \mathrm{C}$ adalah sebagai berikut:

Tabel 2: Hasil Pencampurann dengan Variasi Waktu

\begin{tabular}{cc}
\multicolumn{2}{c}{ Pencampuran } \\
\hline $\begin{array}{c}\text { Waktu } \\
\text { Pencampuran } \\
\text { (menit) }\end{array}$ & $\begin{array}{c}\text { \% Jumlah Produk } \\
\text { Terdispersi }\end{array}$ \\
\hline 14,5 & 1,51 \\
15 & 1,47 \\
17 & 1,42 \\
18 & 0,62 \\
20,5 & 1,10 \\
\hline
\end{tabular}

Tabel 2 menunjukkan hubungan antara \% jumlah produk terdispersi terhadap waktu pencmpuran. Dilihat dari Tabel 2 bahwa waktu pencampuran pada 18 menit memiliki jumlah produk terdispersi sebesar 0,62\%, hasil tersebut terendah dibandingkan dengan waktu yang lain.

\subsection{Hasil Pencampuran dengan Variasi Putaran Rotor}

Hasil pencampuran pada range putaran rotor 20-30 rpm dengan suhu pencampuran $86^{\circ} \mathrm{C}$ dan waktu pencampuran 18 menit adalah sebagai berikut:

Tabel 3: Hasil Pencampuran dengan Variasi Putaran Rotor

\begin{tabular}{cc}
\hline $\begin{array}{c}\text { Putaran Rotor } \\
\text { (rpm) }\end{array}$ & $\begin{array}{c}\text { \% Jumlah Produk } \\
\text { Terdispersi }\end{array}$ \\
\hline 21 & 4,98 \\
23 & 3,42 \\
25 & 2,32 \\
28 & 0,62 \\
30 & 0,49 \\
\hline
\end{tabular}

Berdasarkan Tabel 3 terlihat bahwa pada kondisi putaran rotor $30 \mathrm{rpm}$ memiliki nilai \% jumlah produk terdispersi paling kecil yaitu 0,49\%. Menurut Purwanto (2008) bahwa semakin tinggi putaran rotor akan meningkatkan homogenitas campuran. Dengan nilai \% jumlah produk terdispersi yang kecil saat putaran rotor paling besar, menunjukkan proses pencampuran berjalan dengan lebih sempurna.

\subsection{Hasil Pencampuran pada Kondisi operasi Optimum}

Hasil pencampuran pada kondisi operasi suhu pencampuran, waktu pencampuran, dan putaran rotor pada variasi optimum adalah pada putaran rotor $30 \mathrm{rpm}$, suhu $86^{\circ} \mathrm{C}$, dan waktu pencampuran 18 menit, memperoleh nilai produk terdispersi $0,49 \%$. Berdasarkan kondisi operasi tersebut telah memenuhi target untuk menghasilkan produk terdispersi $<0,5 \%$.

\subsection{Analisis dari Beberapa Pustaka}

Tabel 4.Analisis dari Beberapa Pustaka

\begin{tabular}{|c|c|c|c|c|}
\hline $\begin{array}{l}\text { Kondisi } \\
\text { Operasi }\end{array}$ & $\begin{array}{c}\text { Hasil } \\
\text { Peneli } \\
\text { tian }\end{array}$ & $\begin{array}{c}\text { Honggoku } \\
\text { sumo, } \mathbf{S}\end{array}$ & $\begin{array}{c}\text { DuPo } \\
\text { nt }\end{array}$ & $\begin{array}{c}\text { Choi } \\
\text { dan } \\
\text { Jong }\end{array}$ \\
\hline $\begin{array}{c}\text { Tensile } \\
\text { Strenght } \\
(\mathrm{MPa})\end{array}$ & 10 & - & 15,6 & - \\
\hline $\begin{array}{l}\text { Elongati } \\
\text { on }(\%)\end{array}$ & 750 & - & 770 & - \\
\hline $\begin{array}{c}\text { Hardness } \\
\text { (Shore } \\
\text { A) }\end{array}$ & 40 & - & 50 & - \\
\hline $\begin{array}{l}\text { Waktu } \\
\text { Pencamp } \\
\text { uran } \\
\text { (menit) }\end{array}$ & 18 & 23 & 15 & 20 \\
\hline $\begin{array}{c}\text { Suhu } \\
\text { Pencamp } \\
\text { uran }\left({ }^{\circ} \mathrm{C}\right)\end{array}$ & 86 & 140 & 153 & 160 \\
\hline $\begin{array}{c}\text { Putaran } \\
\text { Rotor } \\
\text { (rpm) }\end{array}$ & 30 & $28-30$ & - & $\begin{array}{l}30- \\
45\end{array}$ \\
\hline
\end{tabular}


Kondisi operasi terbaik pada penelitian yaitu pada waktu pencampuran 18 menit dan suhu pencampuran $86 \mathrm{C}$ menghasilkan persen dispersi $0,49 \%$. Nilai persen dispersi tersebut sudah mencapai target penelitian, tetapi kondisi operasi yang digunakan pada penelitian berbeda dengan literatur DuPont (2008), Honggokusomo, S (1994), Choi dan Jong 2010).

Suhu proses yang terjadi pada penelitian ini berbeda dengan penelitian yang telah dilakukan oleh Honggokusumo, S (1994). Nilai suhu proses untuk karet jenis chloroprene rubber adalah $140^{\circ} \mathrm{C}$ yang menghasilkan efisiensi pencampuran sebesar 26\% (Honggokusumo S, 1994). Penelitan menghasilkan efisiensi sebesar 4,5\%. Nilai efisiensi tersebut rendah, karena suhu pada proses pencampuran yang digunakan lebih rendah dari penelitian yang dilakukan oleh Honggokusumo, S (1994).

Pada penelitian produk chloroprene rubber berfungsi sebagai ball join seal. Dalam proses pencampuran pembuatan karet ball join seal ini memiliki kondisi operasi yaitu waktu pencampuran 15 menit dan suhu pencampuran 153C (DuPont, 2008). Parameter yang diambil sebagai acuan untuk membandingkan kondisi operasi yaitu tensile strength 15,6 MPa, elongation $770 \%$, dan hardness 50 Shore A. Sedangkan kondisi operasi terbaik pada penelitian yaitu 18 menit dan 86C. Berdasarkan data-data tersebut terlihat perbedaan pada kondisi operasi. Perbedaan ini terlihat pada suhu pencampuran yang lebih rendah yaitu 86C dibandingkan DuPont yaitu sebesar 153C.

Dari data-data yang di dapatkan terlihat perbedaan terhadap suhu pencampuran. Perbandingan suhu pencampuran pada penelitian dengan literatur yaitu sebesar $86 \mathrm{C}$ : 160C. Perbedaan ini menyebabkan terdapat dispersi bintik putih pada produk yang dihasilkan dari penelitian dengan kondisi operasi suhu pencampuran yang terlalu rendah. Pada kondisi tersebut bahan-bahan pembuat produk chloroprene rubber tidak terhomogenisasi secara sempurna.

Menurut Honggokusumo (1994) waktu pencampuran paling lama 23 menit, sedangkan Choi dan Jong (2010) waktu pencampuran adalah 20 menit, dan waktu pencampuran oleh DuPont (2008) 15 menit.. Waktu pencampuran yang dipakai pada penelitian adalah 18 menit.Dari data tersebut nilai waktu pencampuran pada penelitian tidak berbeda jauh dengan literatur.

Suhu pencampuran yang disarankan menurut literature adalah lebih atau sama dengan $140^{\circ} \mathrm{C}$, karena akan membuat campuran lebih merata. Sesuai dengan ketiga literature yang menyebutkan suhu pencampuran menurut Honggokusumo $\mathrm{S}$ adalah $140^{\circ} \mathrm{C}$, menurut Sung Seen Choi dan Jong Chul Kim adalah $160^{\circ} \mathrm{C}$, dan DuPont $153^{\circ} \mathrm{C}$. Perbedaan tersebut cukup jauh dengan suhu pencampuran penelitian yang besarnya $86^{\circ} \mathrm{C}$. Hal inilah yang bisa menjadi potensi munculnya bintik putih pada produk karet jenis chloroprene rubber pada penelitian.

Dlihat dari perbandingan kondisi operasi terbaik menurut DuPont dengan penelitian yaitu suhu tinggi dapat mempersingkat waktu proses, sebaliknya pada suhu rendah perlu ditambahkan waktu pencampuran yang lebih lama dari waktu pencampuran pada suhu proses yang tinggi. Hal ini juga sesuai dengan literatur Suharto Honggokusumo yaitu untuk menghasilkan proses pencampuran dengan efisiensi yang tinggi yaitu 26\% dengan waktu pencampuran 23 menit.

Dilihat dari perbandingan suhu pencampuran dan waktu pencampuran menurut Honggokusumo, S (1994) dan DuPont (2008) yaitu 23 menit dan 140C dengan 18 menit dan 153C. Suhu pencampuran menurut Honggokusumo, S lebih kecil dibanding dengan suhu pencampuran menurut DuPont, sedangkan waktu pencampuran menurut DuPont lebih tinggi dibanding dengan waktu pencampuran menurut Honggokusumo, S. 
Hal ini telah menunjukkan bahwa dari hasil penelitian Honggokusumo, S dan literatur menurut DuPont untuk menghasilkan pencampuran yang homogen nilai suhu pencampuran dan waktu pencampuran berbanding terbalik. Apabila suhu pencampuran lebih rendah maka waktu pencampuran harus lebih lama dan pada suhu pencampuran lebih tinggi membutuhkan waktu yang lebih cepat.

Putaran rotor menurut Honggokusumo, S yaitu 20-28 rpm, menurut Sung dan Jong yaitu 30-45 rpm, dan putaran rotor yang digunakan Industri yang diteliti yaitu $21 \mathrm{rpm}$, $23 \mathrm{rpm}, 25 \mathrm{rpm}, 28 \mathrm{rpm}$, dan $30 \mathrm{rpm}$. Putaran rotor tertinggi yaitu pada $30 \mathrm{rpm}$ memiliki persen dispersi bintik putih terendah yaitu $0,49 \%$, sehingga dapat dikatakan bahwa putaran rotor terbaik di Industri yang diteliti adalah $30 \mathrm{rpm}$. Semakin tinggi putaran rotor maka semakin bagus, karena akan menghasilkan panas yang merata, sehingga akan menyebabkan homogenitas yang semakin baik. Begitu pula dengan waktu pencampuran yang lama juga akan meningkatkan homogenitas (Chapman \& Hall, 1949).

Dari bahasan tersebut terlihat bahwa waktu pencampuran, suhu, dan putaran rotor memiliki pengaruh yang kuat untuk terbentuknya bintik putih atau fraksi terdispersi, sehingga suhu pencampuran yang dibutuhkan dalam proses pencampuran chloroprene rubber lebih dari atau sama dengan $140^{\circ} \mathrm{C}$, putaran rotor yang dibutuhkan adalah lebih besar atau sama dengan 30rpm, dan waktu pencampuran yang dibutuhkan yaitu pada rentang 15 sampai 23 menit. Rentang waktu pencampuran tersebut bergantung pada suhu yang digunakan.

\section{SIMPULAN}

Dari analisis data yang dilakukan dapat disimpulkan sebagai berikut:

1) Kondisi operasi yang tidak menyebabkan bintik putih dan memiliki persen dispersi $<0,5 \%$ yaitu pada kondisi operasi suhu $86^{\circ} \mathrm{C}$, waktu pencampuran 18 menit, dan putaran rotor $30 \mathrm{rpm}$ dengan menghasilkan efisiensi pencampuran $4,5 \%$.

2) Kondisi operasi selain suhu, waktu pencampuran, dan putaran rotor dalam kesimpulan 1(satu), menghasilkan produk chloroprene rubber yang terdispersi bintik putih.

\section{DAFTAR PUSTAKA}

1]. Anonim. Tanpa tahun. "Active Minerals: White Crown Clay". (On

Line). Tersedia: http:// www.usinenouvelle.com/ industry/xatico-sarl-35143/activeminerals-white-crown-clayp213197.html [diakses pada tanggal 5 April 2015]

2]. Anonim. 2015. "Chloroprene". (On Line). Tersedia: http:// en.wikipedia .org/wiki /Chloroprene [diakses pada tanggal 1 April 2015]

3]. Anonim. 2015. "Jenis Karet Sintetis". (On Line). Tersedia: http: /id.wikipedia .org/wiki/Jenis_karet [diakses pada 29 April 2015]

4]. Anonim. tt. "Supple Rubber Chemicals". (On Line). Tersedia: http:// www.indiamart.com/supplerubberchemicals/rubber-chemicals.html [diakses pada tanggal 7 April 2015]

5]. Arizal, Dr. Ridha, M.Sc. 1994. "Pengetahuan Dasar Elastomer". Bogor.

6]. Carst, dkk. tt. "Magnesium Oxide". (On Line). Tersedia: http:// www.carst.co.za/ magnesium\%20oxide1.aspx [diakses pada tanggal 7 April 2015]

7]. Chapman \& Hall. 1949. "Modern Synthetic Rubbers". London

8]. Choi, Sung Seen dan Jong Chul Kim.2010. "Chlorine Effect on Thermal Aging Behaviors of BR and CR Composites". (On Line). Tersedia: https:// www.google.co.id/ 
search.Chlorine Effect onThermal Aging Behaviors [ diakses pada 15 Mei 2015 ]

9]. DuPont. 2008. "A Guide to Grades, Compounding and Processing of Neoprene Rubber". (On Line). Tersedia: https://www.google.co.id/www.scribd. comGuide-to-GradesCompoundingandProcessing-ofNeoprene RubberBament Guide [diakses pada 10 Mei 2015]

10]. Honggokusumo, Dr Soeharto. 1994. "Proses Pencampuran". (On Line). Tersedia: www.testingindonesia.com $\% 2$ Fproducts\%2Ffiles\%2FProsesPenca mpuran.ppsx [diakses pada 5 April 2015]

11]. Malcom. P.S. 2001. "Rubber Products Manufacturing Technology".

12]. Matondang. 2010. "Pengenalan Karet Sintetis". (On Line). Tersedia: http://www.google.co.id/Chapter $\% 2520$ II.pdf\&ei=EslAV fvABNC1uASTwYC AAQ\&usg=AFQjCNF4JOKUhL86Pz7 Pkul0WG0xL33PDA\&sig2=178mLzT Fflm4Fzxlw_p_Jw [diakses pada 29 April 2015]

13]. Purwanto, Didik.(2008).Pengaruh Desain Impeller, Baffle eV, dan
Kecepatan Putar pada Proses Isolasi Minyak Kelapa Murni dengan Metode Pengadukan.Seminar Nasional Aplikasi Sains dan Teknologi, IST AKPRIND, Yogyakarta.

14]. Saputra, Satriya. 2013. "Pencampuran (Mixing)". (On Line). Tersedia: http:// satriyasaputra.blogspot.com/2013/09/pe ncampuran-mixing.html [diakses pada 29 April 2015]

15]. Sengupta, Abhijit. 2004. "Ministry Of Commerce \& Industry Departement Of Commerce (Directorate General Of Anti-Dumping \& Allied Duties) Notification". (On Line). Tersedia:http://commerce.nic.in/adint_r ubber_chemicals_chinapr.htm [diakes pada tanggal 5 April 2015]

16]. Xinyuan, Zaozhuang. 2012. "Carbon Black N774”. (On Line). Tersedia: http://

www.xycarbonblack.com/aspcms/produ ct/carbon-black-n774.html [diakses pada tanggal 5 April 2015]

17]. Yuanye, Xinxinang. 2013. "N-(1,3Dimethylbutyl)-N'-Phenylpphenylenediamine".(On Line). Tersedia: http://chemicalland21.com/specialtyche $\mathrm{m} /$ finechem/6PPD.htm [diakses pada tanggal 4 April 2014] 